\title{
Determining utilizable true protein digestibility of mixed rations for sheep using in vitro techniques
}

\author{
Q.-Y. Liu and G.-Y. Zhao ${ }^{1}$ \\ State Key Laboratory of Animal Nutrition, College of Animal Science and Technology, \\ China Agricultural University \\ Beijing 100094, P.R. China
}

\begin{abstract}
The objective of the experiment was to compare in vitro digestion techniques, i.e. 24,48 and $72 \mathrm{~h}$ pepsin digestion, pepsin-small intestinal fluid (SIF) digestion and pepsin-pancreatin digestion, for the determination of in vitro digestibility of utilizable true protein (uTP) of mixed rations for sheep. Twelve typical mixed rations for sheep (CP content 7.64-13.02\% DM) were formulated as feed samples. It was found that there was no significant deference in uTP digestibility of mixed rations between 24,48 and $72 \mathrm{~h}$ pepsin digestion $(\mathrm{P}>0.05)$, whereas uTP digestibility of pepsinSIF treatment was higher than that of pepsin treatment $(\mathrm{P}<0.05)$, and uTP digestibility of pepsinpancreatin treatment was higher than that of all other treatments $(\mathrm{P}<0.05)$. Further research is needed to study the reasons for the difference in in vitro uTP digestibility between pepsin digestion, pepsinSIF digestion and pepsin-pancreatin digestion, and study the relationship between in vitro and in vivo uTP digestibility before a suitable in vitro technique for determining uTP digestibility is proposed.
\end{abstract}

KEY WORDS: utilizable true protein, digestibility, in vitro, sheep

\section{INTRODUCTION}

In ruminants, the utilizable true protein (uTP) of feedstuffs flowing out of rumen to lower digestive tract mainly includes dietary undegradable true protein in rumen and rumen microbial true protein. The uTP of mixed rations for sheep could be estimated using in vitro incubation technique (Li and Zhao, 2007). The uTP digestibility in lower digestive tract is an important index for the evaluation of uTP nutritive value of feedstuffs. In vitro technique was widely used for the determination of dry matter digestibility of feedstuffs (Tilley and Terry, 1963). The aim of the study is to compare in vitro techniques with different enzymes and digestion time

${ }^{1}$ Corresponding author: e-mail: zhaogy@cau.edu.cn 
for the determination of uTP digestibility of mixed rations for sheep. A further aim is to propose an in vitro technique for determining uTP digestibility.

\section{MATERIAL AND METHODS}

Feed samples

Twelve typical rations for sheep ( $\mathrm{Li}$ and Zhao, 2007) with graded levels of CP (7.64-13.02\% DM) were formulated. The composition of the rations was the same as in Li and Zhao (2007).

\section{Rumen fluid donors}

Three male adult sheep, weighing $28.2 \pm 0.7 \mathrm{~kg}$, fitted with rumen cannulas, were used as the donor of rumen fluid. The animals were fed with $1200 \mathrm{~g}$ of total mixed ration. The ration contained $800 \mathrm{~g}$ hay and $400 \mathrm{~g}$ concentrate mixture. The concentrate mixture included, \%: maize 60.3 , soyabean meal 21 , wheat bran 14 , $\mathrm{NaCl} 1.7$, dicalcium phosphate 2 and premix compound 1 . The ration was given to the sheep in two equal meals at 8.00 and $18.00 \mathrm{~h}$, respectively. Fresh water for the sheep was freely available.

\section{Small intestinal fluid (SIF) donor}

One adult sheep weighing $26.0 \mathrm{~kg}$, was slaughtered before morning feeding and all the digesta in the small intestine was collected. The digesta was strained through two layers of surgical gauze into centrifuge tubes. The intestinal fluid was centrifuged at $1000 \mathrm{~g}$ for $15 \mathrm{~min}$ at $4{ }^{\circ} \mathrm{C}$, and the supernatant was freeze-dried in a freeze-dryer (Freezone 6, Labconco, USA). The dried sample was milled through a $1 \mathrm{~mm}$ sieve, and stored at $-50^{\circ} \mathrm{C}$ for later use.

\section{Preparation of in vitro ruminal digesta}

Buffers and buffer-rumen fluid mixture were made up according to Zhao and Lebzien (2000). About $0.5 \mathrm{~g}$ of the mixed rations was weighed into $80 \mathrm{ml}$ glass centrifuge tubes. Each feed sample had three duplicates. Approximately $120 \mathrm{ml}$ rumen fluid was taken from each sheep three $h$ after morning feeding. The rumen fluid from three sheep was well mixed and then strained through four layer of surgical gauze. The buffer-rumen fluid mixture was continuously gassed with $\mathrm{CO}_{2}$ at $38^{\circ} \mathrm{C}$. Fifty $\mathrm{ml}$ of buffer-rumen fluid mixture were transferred into each incubation tube. The samples were incubated at $38^{\circ} \mathrm{C}$ for $24 \mathrm{~h}$. After incubation, 
the incubation residues were dried at $65^{\circ} \mathrm{C}$ for $48 \mathrm{~h}$, then milled through a $3 \mathrm{~mm}$ sieve and was kept at $-20^{\circ} \mathrm{C}$ for later use.

\section{Pepsin digestion}

The pepsin digestion procedure was according to Tilley and Terry (1963). Approximately $0.5 \mathrm{~g}$ dried in vitro ruminal digesta sample was incubated with $50 \mathrm{ml}$ of $0.1 \mathrm{~N} \mathrm{HCl}$ solution containing $20 \mathrm{~g} / 1$ pepsin (Sinopharm Chemical Reagent Co., Ltd.; enzyme activity $1200 \mathrm{u} / \mathrm{g}$ ) in $80 \mathrm{ml}$ centrifuge tubes in three duplicates. The samples were incubated for 24,48 or $72 \mathrm{~h}$ in a water bath at $38^{\circ} \mathrm{C}$. After incubation, the incubation residues were centrifuged at $1800 \mathrm{~g}$ for $30 \mathrm{~min}$ and the supernatant was discarded. The residues were used for determination of TCA-insoluble N.

\section{Pepsin-pancreatin digestion}

The procedures were according to Akeson and Stahmann (1964). Pancreatin solution was made up by dissolving $1.6 \mathrm{~g}$ pancreatin (Sigma, P7545-25G) in $400 \mathrm{ml}$ phosphate buffer (52 ml 0.2 $\left.\mathrm{M} \mathrm{KH}_{2} \mathrm{PO}_{4}+348 \mathrm{ml} 0.2 \mathrm{M} \mathrm{Na}_{2} \mathrm{HPO}_{4} ; \mathrm{pH} 7.6\right)$. Approximately $0.5 \mathrm{~g}$ dried in vitro ruminal digesta sample was incubated with $50 \mathrm{ml}$ of $0.1 \mathrm{~N} \mathrm{HCl}$ solution containing $20 \mathrm{~g} / \mathrm{l}$ pepsin in $80 \mathrm{ml}$ centrifuge tubes in three duplicates. The samples were incubated in a water bath at $38^{\circ} \mathrm{C}$ for $3 \mathrm{~h}$. At the end of incubation, the incubation residues were neutralized with $5 \mathrm{ml}$ of $1 \mathrm{~N} \mathrm{NaOH}$ and centrifuged at $2400 \mathrm{~g}$ for 30 min. The supernatant was discarded and $10 \mathrm{ml}$ freshly-made pancreatin solution was added into each tube containing incubation residues. The tubes were then incubated at $38^{\circ} \mathrm{C}$ in a water bath for $24 \mathrm{~h}$. At the end of incubation, the samples were centrifuged at $2400 \mathrm{~g}$ for $15 \mathrm{~min}$ and the supernatant was discarded. The residues were used for the determination of TCA-insoluble $\mathrm{N}$.

\section{Pepsin-SIF digestion}

About $3.6 \mathrm{~g}$ freeze-dried SIF was dissolved in $400 \mathrm{ml}$ phosphate buffer $(52 \mathrm{ml}$ $0.2 \mathrm{M} \mathrm{KH}_{2} \mathrm{PO}_{4}+348 \mathrm{ml} \mathrm{0.2} \mathrm{M} \mathrm{Na}_{2} \mathrm{HPO}_{4} ; \mathrm{pH}$ 7.6). The procedures were similar to those of pepsin-pancreatin digestion. In SIF digestion, the volume of SIF buffer used in each tube was $20 \mathrm{ml}$.

\section{Determination and chemical analysis}

All samples were dried at $105^{\circ} \mathrm{C}$ for $6 \mathrm{~h}$ for dry matter (DM) determination. The true protein of the samples was determined using the TCA method (Licitra et al., 1996). The filter paper together with the residues was used for nitrogen determination using the Kjeldahl method. 


\section{Calculation}

The digestibility of true protein was calculated as following:

$$
\text { uTP } \text { - digestibility }=\left(\mathrm{TP}_{1}-\mathrm{TP}_{2}\right) / \mathrm{TP}_{1} \times 100
$$

where: uTP-digestibility refers to utilizable true protein digestibility, $\%$; $\mathrm{TP}_{1}$, true protein content in in vitro digesta sample, $\mathrm{g}$; $\mathrm{TP}_{2}$, true protein content in residue after pepsin digestion, pepsin-SIF digestion or pepsin-pancreatin digestion, $\mathrm{g}$.

\section{Statistical analysis}

The EXCELL 2003 was used for one-way analysis of variance of the results between different treatments.

\section{RESULTS}

The results indicated that although uTP digestibility of $48 \mathrm{~h}$ pepsin digestion was slightly higher than that of 24 and $72 \mathrm{~h}$ pepsin digestion, the difference in uTP digestibility between 24,48 and $72 \mathrm{~h}$ pepsin digestion did not reach significant level $(\mathrm{P}>0.05)$.

Table 1. In vitro digestibility of utilizable true protein of mixed rations, $\% \mathrm{DM}$

\begin{tabular}{|c|c|c|c|c|c|}
\hline \multirow{2}{*}{ Rations } & \multicolumn{3}{|c|}{ Pepsin } & \multirow{2}{*}{ SIF } & \multirow{2}{*}{ Pancreatin } \\
\hline & $24 \mathrm{~h}$ & $48 \mathrm{~h}$ & $72 \mathrm{~h}$ & & \\
\hline 1 & $59.41 \pm 0.36$ & $59.39 \pm 0.73$ & $57.06 \pm 0.69$ & $62.14 \pm 0.20$ & $74.77 \pm 0.13$ \\
\hline 2 & $66.42 \pm 0.57$ & $65.74 \pm 0.77$ & $64.51 \pm 0.59$ & $73.29 \pm 0.27$ & $75.09 \pm 0.26$ \\
\hline 3 & $57.59 \pm 0.41$ & $59.42 \pm 0.65$ & $58.26 \pm 0.47$ & $66.99 \pm 0.24$ & $75.35 \pm 0.26$ \\
\hline 4 & $69.82 \pm 0.63$ & $70.54 \pm 0.07$ & $69.35 \pm 0.68$ & $66.30 \pm 0.44$ & $76.79 \pm 0.23$ \\
\hline 5 & $63.86 \pm 0.41$ & $63.84 \pm 0.47$ & $62.77 \pm 0.48$ & $71.45 \pm 0.11$ & $77.76 \pm 0.15$ \\
\hline 6 & $59.26 \pm 0.49$ & $59.46 \pm 0.51$ & $59.19 \pm 0.60$ & $66.72 \pm 0.62$ & $72.47 \pm 0.40$ \\
\hline 7 & $60.54 \pm 0.38$ & $61.66 \pm 0.49$ & $60.21 \pm 0.15$ & $72.89 \pm 0.06$ & $74.56 \pm 0.00$ \\
\hline 8 & $61.93 \pm 0.40$ & $61.42 \pm 0.77$ & $59.00 \pm 0.59$ & $70.67 \pm 0.20$ & $75.34 \pm 0.23$ \\
\hline 9 & $59.23 \pm 0.35$ & $59.07 \pm 0.60$ & $58.42 \pm 0.47$ & $74.53 \pm 0.50$ & $79.86 \pm 0.11$ \\
\hline 10 & $59.87 \pm 0.20$ & $60.30 \pm 0.41$ & $58.98 \pm 0.17$ & $63.64 \pm 0.34$ & $81.01 \pm 0.35$ \\
\hline 11 & $57.59 \pm 0.70$ & $59.04 \pm 0.85$ & $57.42 \pm 0.35$ & $58.61 \pm 0.46$ & $80.68 \pm 0.35$ \\
\hline 12 & $55.60 \pm 1.55$ & $52.98 \pm 1.01$ & $53.02 \pm 0.90$ & $61.69 \pm 0.03$ & $76.81 \pm 0.12$ \\
\hline Mean & $60.93 \pm 0.81^{\mathrm{a}}$ & $61.07 \pm 0.90^{\mathrm{a}}$ & $59.85 \pm 0.88^{a}$ & $67.41 \pm 1.04^{b}$ & $76.70 \pm 0.53^{\circ}$ \\
\hline
\end{tabular}

values with different superscripts mean significant difference $(\mathrm{P}<0.05)$ 
uTP-digestibility of pepsin-SIF that digestion was significantly higher than of pepsin treatment $(\mathrm{P}<0.05)$. The uTP digestibility of pepsin-SIF digestion was about 7 percentage points higher than that of 24,48 and $72 \mathrm{~h}$ pepsin digestion. Results also showed that uTP-digestibility of pepsin-pancreatin digestion was higher than that of pepsin digestion and that pepsin-SIF digestion $(\mathrm{P}<0.05)$.

\section{DISCUSSION}

The results implied that the uTP of the samples could be completely digested within $24 \mathrm{~h}$. Longer time digestion would not increase in vitro digestibility of uTP. The reasons for the difference between pepsin digestion and pepsin-SIF and pepsin-pancreatin digestion could be that the enzymes and the incubation time were different. In the future, it was necessary to study the reasons for the difference between different treatments and also study the relationship between in vitro uTP digestibility and in vivo digestibility, so that a suitable in vitro method for determining uTP digestibility could be proposed.

\section{CONCLUSIONS}

No significant difference in in vitro digestibility of utilizable true protein (uTP) of mixed rations was found between 24, 48 and $72 \mathrm{~h}$ pepsin digestion. The in vitro uTP digestibility of pepsin-small intestinal fluid (SIF) and pepsin-pancreatin digestion was significantly higher than that of pepsin digestion. Further research is needed to study the reasons for the difference between pepsin digestion, pepsinSIF digestion and pepsin-pancreatin digestion. It is also necessary to study the relationship between in vitro and in vivo uTP digestibility of feedstuffs before a suitable in vitro technique for determining of uTP digestibility is proposed.

\section{REFERENCES}

Akeson W.R., Stahmann M.A., 1964. A pepsin pancreatin digest index of protein quality evaluation. J. Nutr. 83, 257-261

Li Y.X., Zhao G.Y., 2007. Prediction of utilizable true protein of mixed rations for sheep using an in vitro incubation technique. Arch. Anim. Nutr. 61, 203-213

Licitra G., Hernandez T.M., Van Soest P.J., 1996. Standardization of procedures for nitrogen fractionation of ruminant feeds. Anim. Feed Sci. Tech. 57, 347-358

Tilley J.M.A., Terry R.A., 1963. A two-stage technique for the in vitro digestion of forage crops. J. Brit. Grassl. Soc. 18, 104-111

Zhao G.Y., Lebzien P., 2000. Development of an in vitro incubation technique for the estimation of the utilizable crude protein (uCP) in feeds for cattle. Arch. Anim. Nutr. 53, 293-392 